ISSN (Online) 2722-1083,

VOL 2 NO 1 OKTOBER 2021

Click here and write your Article Category

\title{
Adaptasi Masyarakat Menghadapi Kebiasaan Baru di Masa Pandemi Covid 19 di Wilayah Kerja Puskesmas Siatas Barita Tahun 2020
}

\author{
Naomi Isabella Hutabarat ${ }^{1}$, Janner Pelanjani Simamora ${ }^{2}$ \\ ${ }^{1}$ Prodi D III Kebidanan Tarutung Poltekkes Kemenkes
}

\section{ARTICLE INFORMATION}

Received: February 00, 00

Revised: March 00, 00

Available online: April 00, 00

\section{KEYWORDS}

Five words maximum, comma separated

\section{CORRESPONDENCE}

Phone: +62 (0751) 12345678

E-mail: first_author@affiliation.xx.xx

\begin{abstract}
A B $\mathbf{S}$ T $\mathbf{R}$ A $\mathbf{C}$ T
Adaptasi kebiasaan baru adalah agar kita bisa bekerja, belajar dan beraktivitas dengan produktif di era Pandemi Covid-19. New Normal adalah suatu tindakan atau perilaku yang dilakukan oleeh masyarakat dan semua institusi yang ada di wilayah tersebut untuk melakukan pola harian, pola kerja atau pola hidup baru yang berbeda dengan sebelumnya. Bila hal ini tidak dilakukan, akan terjadi resiko penularan. Kegiatan Pengabdian Masyarakat ini memiliki tujuan untuk mewujudkan salah satu kegiatan Tri darma Perguruan Tinggi dan meningkatkan pengetahuan dan kedisiplinan masyarakat tentang Adaptasi Masyarakat menuju kebiasaan baru di masa Pandemi Covid-19 di Wilayah Kerja Puskesmas Siatas Barita. Kebiasaan baru untuk hidup lebih sehat harus terus menerus dilakukan di masyarakat, sehingga menjadi normal social dalam kehidupan sehari hari. Bila kebiasaan baru tidak dilakukan secara disiplin atau hanya dilakukan oleh sekelompok orang saja, maka hal ini bisa menjadi ancaman wabah penularan virus corona covid-19. Kebiasaan lama yang sering dilakukan, seperti bersalaman, cipika-cipiki, cium tangan, berkerumun/bergerombol, malas cuci tangan harus mulai ditinggalkan karena mendukung penularan Covid-19. Hasil dari kegiatan Pengabdian Masyarakat ini adalah diharapkan bahwa masyarakat membutuhkan penyuluhan dan pengetahuan akan pentingnya memelihara kesehatan agar terhindar dari covid-19. Semakin meningkatnya penerapan adaptasi kebiasaan baru dan seiring waktu berjalan pola hidup dengan adaptasi kebiasaan baru sudah menjadi budaya baru, gaya baru yang terjadi saat ini dari mulai anggota keluarga berada dalam lingkungan keluarga di rumah maupun dalam beraktivitas keluar dengan contoh selalu menggunakan masker khususnya saat beraktivitas keluar rumah, meenjaga jarak dengan orang lain, tidak bersentuhan di sembarang tempat.

Kata Kunci: Penyuluhan, Adaptasi kebiasaan baru, Masker, Handsanitaizer.
\end{abstract}

\section{A $\mathbf{B} \mathbf{S}$ T $\mathbf{R}$ A $\mathbf{C} \mathbf{T}$}

The adaptation of new habits is so that we can work, study and do activities productively in the era of the Covid-19 Pandemic. New Normal is an action or behavior carried out by the community and all institutions in the area to carry out daily patterns, work patterns or new patterns of life that are different from before. If this is not done, there will be a risk of transmission. This Community Service activity has the aim of realizing one of the Tri Dharma activities of Higher Education and increasing community knowledge and discipline about Community Adaptation towards new habits during the Covid-19 Pandemic in the Work Area of the Siatas Barita Health Center. New habits for a healthier life must be continuously carried out in the community, so that it becomes a social normal in everyday life. If new habits are not carried out in a disciplined manner or only carried out by a group of people, then this can become a threat to the spread of the corona virus covid-19. Old habits that are often carried out, such as shaking hands, kissing, kissing hands, crowding / in groups, being lazy to wash hands must be abandoned because they support the transmission of Covid-19. The result of this Community Service activity is that it is hoped that the community needs counseling and knowledge about the importance of maintaining health in order to avoid COVID-19. The increasing application of adaptation of new habits and over time the pattern of living with adaptation of new habits has become a new culture, a new style that is happening at this time from the start of family members being in the family environment at home or in outdoor activities by example always using a mask, especially when going out. home, keep a distance from other people, do not touch in any place.

Keywords: Counseling, Adaptation of new habits, Masker, Handsanitaizer.

Kota Wuhan, Tiongkok, bulan Desember 2019. Covid-19 itu sekarang menjadi pandemi yang terjadi di banyak Negara (WHO, 2020). Corona virus adalah suatu kelompok virus yang dapat menyebabkan penyakit pada hewan atau manusia. Beberapa jenis corona virus diketahui menyebabkan infeksi saluran nafas pada manusia mulai dari batuk pilek hingga yang lebih serius seperti Middle East Respiratory Syndrome (MERS) oleh jenis corona virus yang baru ditemukan. Virus baru dan penyakit yang disebabkannya tidak dikenal sebelum mulainya di 
ISSN (Online) 2722-1083,

VOL 2 NO 1 OKTOBER 2021

dan Severe Acute Respiratory Syndrome (SARS) (Kemenkes, 2020).

Gejala-gejala COVID-19 yang paling umum adalah demam, batuk kering, dan rasa lelah. Gejala lainnya yang lebih jarang dan mungkin dialami beberapa pasien meliputi rasa nyeri dan sakit, hidung tersumbat, sakit kepala, konjungtivitis, sakit tenggorokan, diare, kehilangan indera rasa atau penciuman, ruam pada kulit, atau perubahan warna jari tangan atau kaki. Gejala-gejala yang dialami biasanya bersifat ringan dan muncul secara bertahap. Beberapa orang menjadi terinfeksi tetapi hanya memiliki gejala ringan.

Sekitar 1 dari 5 orang yang terinfeksi COVID-19 menderita sakit parah dan kesulitan bernapas. Orang-orang lanjut usia (lansia) dan orang-orang dengan kondisi medis penyerta seperti tekanan darah tinggi, gangguan jantung dan paru-paru, diabetes, atau kanker memiliki kemungkinan lebih besar mengalami sakit lebih serius. Namun, siapa pun dapat terinfeksi COVID-19 dan mengalami sakit yang serius. Orang dari segala usia yang mengalami demam dan/atau batuk disertai dengan kesulitan bernapas/sesak napas, nyeri/tekanan dada, atau kehilangan kemampuan berbicara atau bergerak harus segera mencari pertolongan medis. Jika memungkinkan, disarankan untuk menghubungi penyedia layanan kesehatan atau fasilitas kesehatan terlebih dahulu, sehingga pasien dapat diarahkan ke fasilitas kesehatan yang tepat.

Jika mengalami gejala ringan, seperti batuk ringan atau demam ringan, secara umum tidak perlu mencari pertolongan medis. Tetap di rumah, isolasi diri, dan pantau gejala. Ikuti panduan nasional tentang isolasi mandiri. Namun, jika tinggal di daerah dengan malaria atau demam berdarah, kita tidak boleh mengabaikan gejala demam. Segera cari pertolongan medis. Saat pergi ke fasilitas kesehatan, kenakan masker jika memungkinkan, jaga jarak setidaknya 1 meter dari orang lain, dan jangan menyentuh permukaan benda dengan tangan. Jika yang sakit adalah anak, bantu anak untuk mematuhi nasihat ini. Segera cari perawatan medis jika mengalami kesulitan bernapas atau nyeri/tekanan di dada. Jika memungkinkan, hubungi penyedia layanan kesehatan terlebih dahulu, sehingga dapat diarahkan ke fasilitas kesehatan yang tepat.

Orang dapat tertular COVID-19 dari orang lain yang terinfeksi virus ini. COVID-19 dapat menyebar terutama dari orang ke orang melalui percikan-percikan dari hidung atau mulut yang keluar saat orang yang terinfeksi COVID-19 batuk, bersin atau berbicara. Percikan-percikan ini relatif berat, perjalanannya tidak jauh dan jatuh ke tanah dengan cepat. Orang dapat terinfeksi COVID-19 jika menghirup percikan orang yang terinfeksi virus ini. Oleh karena itu, penting bagi kita untuk menjaga jarak minimal 1 meter dari orang lain. Percikanpercikan ini dapat menempel di benda dan permukaan lainnya di sekitar orang seperti meja, gagang pintu, dan pegangan tangan. Orang dapat terinfeksi dengan menyentuh benda atau permukaan tersebut, kemudian menyentuh mata, hidung, atau mulut mereka. Inilah sebabnya penting untuk mencuci tangan secara teratur dengan sabun dan air bersih mengalir, atau membersihkannya dengan cairan antiseptik berbahan dasar alkohol.

Banyak orang yang terinfeksi COVID-19 hanya mengalami gejala ringan terutama pada tahap-tahap awal. Karena itu, COVID-19 dapat menular dari orang yang hanya bergejala ringan, seperti batuk ringan, tetapi merasa sehat. Beberapa laporan menunjukkan bahwa orang tanpa gejala dapat menularkan virus ini namun belum diketahui seberapa sering penularan dengan cara tersebut terjadi.

Beberapa bulan ini kita hidup penuh dengan berita tentang Covid-19, di TV, radio, media sosial atau media digital, obrolan di rumah, di kantor, dan di telepon juga bicara tentang Covid-19. Berbagai respon dan reaksi ditunjukkan oleh masyarakat, ada yang sedih, cemas, takut, gemas, khawatir, marah-marah, tetapi ada juga yang tenang atau tetap percaya diri (Kemenkes, 2019)

Covid-19 berhasil mengubah kebiasaan yang kita lakukan sehari-hari baik di rumah, di sekolah, di tempat kerja, di jalan, dan dimanapun. Kita dibuatnya seakan tak berdaya, karena gerak langkah kita dibatasi dengan adanya Covid-19, sehingga membuat kita tidak produktif yang berdampak pada masalah ekonomi keluarga, masyarakat, daerah dan negara.

Penyakit ini belum ada obat/vaksinnya dan sudah menjadi pandemi yang menyebabkan banyak kematian di dunia maupun di Indonesia dan sampai saat ini kasusnya masih terus meningkat. Untuk melawan virus ini hal utama yang perlu kita lakukan adalah melakukan tindakan pencegahan seperti: sering cuci tangan pakai sabun, menerapkan etika batuk/pakai masker, meningkatkan daya tahan tubuh, menjaga jarak dan hindari kerumunan. Intinya harus selalu berperilaku hidup bersih dan sehat (PHBS). Kelihatannya hal ini sepele, tetapi kenyataannya masih cukup banyak yang tidak melakukan hal tersebut.

Kementerian Kesehatan beserta jajarannya di daerah tak henti-hentinya melakukan sosialisasi, edukasi kepada masyarakat agar paham apa yang harus dilakukan supaya terhindar dari Covid-19. Namun, hasilnya masih belum memuaskan karena kasusnya masih terus meningkat. Terbukti kasus pertanggal 18 Juli 2020 di Indonesia bertambah 1752 kasus menjadi 84.882 yang terkonfirmasi positif korona mulai dari bulan maret. Provinsi Sumatera Utara termasuk dalam urutan 8 provinsi tertinggi secara nasional pertambahan Covid 19 dengan jumlah kasus keseluruhan sampai tanggal 18 Juli 2020 sebanyak 2923 kasus. Kabupaten Tapanuli Utara diperoleh data kasus yang terkonfirmasi positif sampai Juni 2020 sebanyak 6 kasus. Dari 6 kasus ini sudah sembuh 3 orang.

Pada masa pandemi masyarakat Indonesia diharuskan hidup dengan tatanan hidup baru, yang dapat ,berdamaiee dengan COVID-19. Adapun yang dimaksud dengan New Normal adalah suatu tindakan atau perilaku yang dilakukan oleh masyarakat dan semua institusi yang ada di wilayah tersebut untuk melakukan pola harian atau pola kerja atau pola hidup baru yang berbeda dengan sebelumnya. Bila hal ini tidak dilakukan, akan terjadi risiko penularan. Tujuan dari New Normal adalah agar masyarakat tetap produktif dan aman dari Covid-19 di masa pandemi. 
"New Normal" dinarasikan menjadi "Adaptasi Kebiasaan Baru”. Maksud dari adaptasi kebiasaan baru adalah agar kita bisa bekerja, belajar dan beraktivitas dengan produktif di era Pandemi Covid-19. Hal ini bisa dilakukan kalau kita beradaptasi dengan kebiasaan baru yaitu disiplin hidup sehat dengan menerapkan protokol kesehatan secara ketat.

Kebiasaan baru untuk hidup lebih sehat harus terus menerus dilakukan di masyarakat dan setiap individu, sehingga menjadi normal sosial dan norma individu baru dalam kehidupan sehari hari. Bila kebiasaan baru tidak dilakukan secara disiplin atau hanya dilakukan oleh sekelompok orang saja, maka hal ini bisa menjadi ancaman wabah gelombang kedua. Kebiasaan lama yang sering dilakukan, seperti bersalaman, cipika-cipiki, cium tangan, berkerumun/ bergerombol, malas cuci tangan harus mulai ditinggalkan karena mendukung penularan Covid-19.

Kita dituntut untuk mampu mengadaptasi/ menyesuaikan kebiasaan baru dimanapun kita berada, seperti di rumah, di kantor, di sekolah, di tempat ibadah, dan juga di tempat-tempat umum, seperti terminal, pasar, dan mal. Diharapkan dengan seringnya menerapkan kebiasaan baru dimanapun, semakin mudah dan cepat menjadi norma individu dan norma masyarakat.

Berdasarkan uraian diatas, kami tim Pengabdian masyarakat Program Studi D III Kebidanan Tarutung Poltekkes Kemenkes Medan tertarik untuk melakukan pengabdian masyarakat dengan kegiatan penyuluhan dengan judul "Adaptasi Masyarakat menuju kebiasaan baru di Masa Pandemi Covid 19 di Wilayah kerja Puskesmas Siatas Barita Tahun 2020.

Kegiatan Pengabdian Masyarakat ini memiliki beberapa tujuan antara lain :

a. Mewujudkan salah satu kegiatan Tri darma Perguruan Tinggi.

b. Meningkatkan pengetahuan dan kedisiplinan masyarakat tentang adaptasi masyarakat menuju kebiasaan baru di masa pandemic Covid-19 di Wilayah Kerja Puskesmas Siatas Barita Tahun 2020.

\section{METHOD}

Kegiatan pengabdian masyarakat ini dilakukan pada hari Sabtu 20 Agustus 2020 dan 12 September 2020 bertempat di Desa Lumban Ratus, Sangkaran, Lumban Siagian dan Pancurnapitu yang termasuk dalam Wilayah kerja Puskesmas Siatas Barita Kabupaten Tapanuli Utara dengan memberikan penyuluhan tentang Adaptasi masyarakat menuju kebiasaan baru di masa pandemic Covid-19 yang dihadiri oleh Kepala desa beserta perangkatnya, Bidan Desa, Tim Pengabdi dan ibu hamil. Yang menjadi sasaran dalam Kegiatan ini adalah ibu hamil yang berjumlah 50 orang. Penyuluhan yang diberikan kepada ibu hamil berupa penyuluhan adaptasi masyarakat menuju kebiasaan baru dan pembagian masker. upaya Pencegahan dan cara mengatasi Covid-19 Pada Ibu hamil dan memberitahu ibu untuk mencuci tangan. Dalam pengabdian ini juga dilakukan Simulasi cara membuat Handsanitizer.

\section{HASIL DAN PEMBAHASAN}

Hasil yang diperoleh dari kegiatan Penyuluhan adaptasi masyarakat menghadapi kebiasaan baru di masa pandemi covid 19 di wilayah kerja puskesmas siatas barita pada tanggal 20 November 2020 dengan jumlah 50 orang peserta.

Selanjutnya dilakukan pendidikan kesehatan dengan penyuluhan tentang mencuci tangan diair mengalir dengan 7 langkah, memakai masker dan menghindari kerumunan.

Menurut Maulana (2009), ceramah adalah pidato yang disampaikan oleh sorang pembicara di depan sekelompok pengunjung atau pendengar. Metode ini dipergunakan jika berada dalam kondisi seperti waktu penyampaian informasi

terbatas, orang yang mendengarkan sudah termotivasi, pembicara menggunakan gambar dalam kata-kata, kelompok terlalu besar untuk memakai metode lain, ingin menambahkan atau menekankan apa apa yang sudah dipelajar dan mengulangi, memperkenalkan atau mengantarkan apa yang sudah dicapai.

Menurut Mubarak, dkk (2007), metode ceramah adalah cara penyampaian bahan pelajaran dengan komunikasi lisan. Metode ceramah yang ekonomis dan efektif untuk keperluan penyampaian informasi dan pengertian. Metode ceramah hanya cocok untuk menyampaikan informasi, bila bahan ceramah langka, kalau organisasi sajian harus disesuaikan dengan sifat penerima, bila perlu membangkitkan minat, bahan cukup diingat

sebentar dan untuk memberi pengantar atau petunjuk bagi

format lain. Menurut Depkes (2002) ceramah adalah salah satu cara untuk menyampaikan pelajaran dalam bentuk penjabaran/penjelasan oleh instruktur terhadap peserta. Menurut

Depkes (2007), ceramah dapat dilakukan kepada kelompok dengan ukuran kecil dan besar. Ceramah sangat efektif untuk memperkenalkan subjek baru, atau mempersentasikan kesimpulan ataupun kajian kepada para peserta. Ceramah yang efektif dilakukan tahap demi tahap dan didukung oleh alat bantu. Ceramah yang baik adalah ceramah yang dipersiapkan sebelumnya dengan memasukkan keterlibatan aktif para peserta.

Kegiatan Pengabdian masyarakat ini juga melakukan Simulasi cara membuat Handsanitizer. Adapun cara membuat hand sanitizer sesuai standar WHO adalah sebagai berikut : Pilih formula hand sanitizer yang Anda inginkan. Lalu masukkan Ethanol (untuk formula 1) atau Isopropil alkohol (untuk formula 2) sesuai takaran ke dalam jerigen; Masukkan cairan hidrogen peroksida ke dalam jerigen sesuai takaran; Masukkan gliserin karena bersifat lengket dan kental dapat juga diganti dengan aloevera ( Lidah buaya) dan Anda bisa

menggunakan sedikit air steril untuk membilas gliserin dalam gelas ukur sebelum memasukkannya ke jerigen; Setelah seluruh bahan dimasukkan dalam 1 jerigen, masukkan 1 liter air distilasi dan jangan lupa tutup jerigen agar alkohol tidak menguap; Kocok jerigen secara perlahan agar ketiga bahan tersebut bisa tercampur dengan rata; Tak butuh waktu lama, hand sanitizer pun siap dipindahkan ke botol-botol yang lebih kecil agar mudah dibawa; Terakhir, simpan botol-botol ini selama 72 
ISSN (Online) 2722-1083,

VOL 2 NO 1 OKTOBER 2021

jam (kurang lebih 3 hari) untuk menghindari kontaminasi dari botol; Hand sanitizer sudah siap dibawa dan digunakan.Hal ini perlu diketahui oleh ibu hamil agar terhindar dari Covid-19. Selain itu, tetap menjaga protokol kesehatan yaitu memakai masker, mencuci tangan atau menggunakan handsanitezer, dan menjaga jarak. Dengan adanya kegiatan ini, ibu hamil menjadi paham tentang pencegahan infeksi COVID-19 bagi ibu hamil, prosedur pemeriksaan kehamilan di era pandemi, cara menjaga kesehatan ibu hamil di era pandemi, upaya yang dilakukan ketika ibu hamil sakit di era pandemi. Peningkatan pengetahuan tersebut juga diharapkan ibu hamil tetap bersedia memeriksakan kehamilannya secara teratur untuk memantau pertumbuhan dan perkembangan janin dengan tetap memperhatikan protokol kesehatan. Hal tersebut sejalan dengan tujuan edukasi yaitu mengembangkan perilaku positif dalam rangka meningkatkan kesehatan (Maulana, 2009).

\section{KESIMPULAN}

Pemahaman ibu hamil tentang kebiasaan baru pada Ibu hamil dalam Pemeriksaan ANC dimasa Pandemi Covid-19 berguna untuk pencegahan infeksi COVID-19 bagi ibu hamil, prosedur pemeriksaan kehamilan di era pandemi, cara menjaga kesehatan ibu hamil di era pandemi, upaya yang dilakukan ketika ibu hamil sakit di era pandemi, yang kemudian menyadari untuk tetap memeriksakan kehamilannya selama pandemi COVID-19 dengan menerapkan protocol kesehatan agar pertumbuhan dan perkembangan janin dapat terpantau dengan baik.

\section{REFERENCES}

(1) Tim Gugus Tugas PPC-19 Nasional

(2) Covid-19 Communication Network Johns Hopkins Bloomberg, 2020, Synthesized Guidance for covid 19 Message Development, School Public Health

(3) Kemenkes, 2020, Kebiasaan Adaptasi Baru, http://promkes.kemkes.go.id/menuju-adaptasikebiasaan-baru, diakses 18 Juli 2020

(4) Putri Ade Suzanna Eka, 2017, Peningkatan aktivitas fisik dan pemanfaatan rumah untuk tanaman sayur dan buah sebagai gerakan masyarakat hidup sehat (GERMAS) di Kecamatan Kuranji, Padang

(5) WHO, Public Health Criteria to Adjust Public Health and Social measures in the Context of Covid-19, May 2020

Biodata Penulis I :

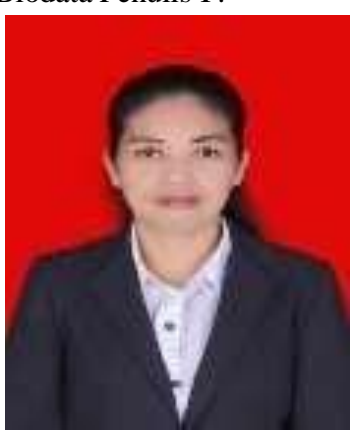

Naomi Isabella Hutabarat, SST, M.Kes lahir pada tanggal 27 Februari 1975 di Pematang Siantar Provinsi Sumatera Utara, dari pasangan Drs. Pontigor Hutabarat (Alm) dan Ibu Dra. Mery Miduk Situmeang (Alm). Jenjang Pendidikan tinggi Penulis dimulai dari D III Keperawatan Deli Husada Deli Tua lulus tahun 1996, D IV Perawat Pendidik Universitas Sumatera
Utara lulus tahun 2005, S2 Ilmu Kesehatan Masyarakat Universitas Sumatera Utara minat studi Kesehatan Reproduksi lulus tahun 2015. Pada saat ini penulis bekerja sebagai dosen tetap di Program Studi D III Kebidanan Tarutung Poltekkes Kemenkes Medan (Homebase). Penulis mengampu Mata Kuliah Keterampilan Klinik Praktik Kebidanan (KKPK I \& II), Asuhan Kebidanan Neonatus, Bayi dan Balita, Anatomi Fisiologi, Hypnoterapi dan Metode Alternatif lainnya dalam asuhan kebidanan, serta menulis artikel yang dipublikasikan dijurnal nasional terakreditasi dan Internasional.

Biodata Penulis II :

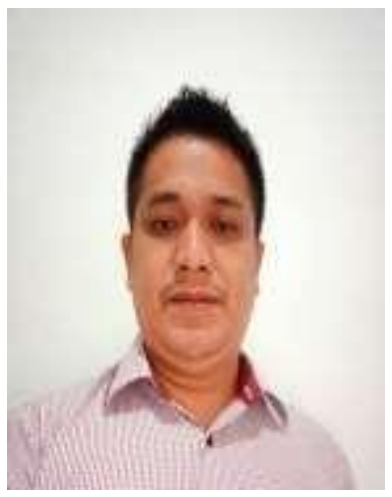

Janner Pelanjani Simamora, SKM, M.Kes lahir pada tanggal 08 Jannuari 1986 di Dolok Sanggul Sumatera Utara, dari pasangan D. Simamora (Alm) dan Ibu L. Br. Manullang. Jenjang Pendidikan tinggi Penulis dimulai dari D III Keperawatan Teladan Bahagia Medan lulus tahun 2007, S1 Kesehatan Masyarakat Universitas Prima Indonesia lulus tahun 2009, S2 Ilmu Kesehatan Masyarakat Universitas Sumatera Utara minat studi AKK/Epidemiologi lulus tahun 2012. Pada saat ini penulis bekerja sebagai dosen tetap di Program Studi D III Kebidanan Tarutung Poltekkes Kemenkes Medan (Homebase). 